\title{
The pore pressure oscillation method as a proven tool for determining the hydraulic properties of low-permeability rocks
}

\author{
Lisa Winhausen, Mohammadreza Jalali, and Florian Amann \\ Department of Engineering Geology and Hydrogeology, RWTH Aachen University, Aachen, Germany \\ Correspondence: Lisa Winhausen (winhausen@lih.rwth-aachen.de)
}

Published: 10 November 2021

\begin{abstract}
In the context of selecting and designing a future repository site for nuclear waste, a proper understanding of the host rock's physical behavior is required. One of the fundamental characteristics is the hydraulic diffusivity of the host rock, i.e., the ratio between permeability and storativity. For low-permeability rocks, however, determination of these properties is technically challenging and often time consuming.

Among various steady-state and transient methods, the pore pressure oscillation technique has been proven to be an advantageous method for the simultaneous measurement of permeability and storativity for potential host rocks on a laboratory scale.

In this contribution, we will introduce the methodological approach and highlight the advantages and disadvantages compared to other methods. Furthermore, we will demonstrate the applicability of this method for clay-rich rocks by presenting our experimental results. Carefully chosen boundary conditions allow us to constrain dependencies of the properties on, e.g., effective stress or bedding orientation with respect to the fluid flow direction. Additionally, this method is practical for measuring the damage-induced changes of permeability and storativity due to differential loading.
\end{abstract}

Kurzfassung. Im Zusammenhang mit der Auswahl und Planung eines künftigen Endlagerstandorts für nukleare Abfälle ist ein gründliches Verständnis des physikalischen Verhaltens des Wirtsgesteins erforderlich. Eine der grundlegenden Eigenschaften ist die hydraulische Diffusivität des Wirtsgesteins, d.h. das Verhältnis zwischen Durchlässigkeit und Speicherfähigkeit. Bei Gesteinen mit geringer Durchlässigkeit ist die Bestimmung dieser Eigenschaften jedoch eine technische Herausforderung und oft zeitaufwändig.

Unter verschiedenen stationären und instationären Methoden hat sich im Labormaßstab die Porendruckoszillation-Technik als geeignetes Verfahren zur gleichzeitigen Messung von Permeabilität und Speicherfähigkeit für potenzielle Wirtsgesteine erwiesen.

In diesem Beitrag werden der methodische Ansatz vorgestellt und die Vor- und Nachteile im Vergleich zu anderen Methoden aufgezeigt. Darüber hinaus werden wir die Anwendbarkeit dieser Methode für tonreiche Gesteine anhand unserer experimentellen Ergebnisse demonstrieren. Sorgfältig gewählte Randbedingungen ermöglichen es uns, die Abhängigkeit der Eigenschaften z. B. von der effektiven Spannung oder der Orientierung der Schichtung in Bezug auf die Fließrichtung einzugrenzen. Darüber hinaus ist diese Methode geeignet für die Messung der schädigungsbedingten Änderungen der Permeabilität und Speicherfähigkeit bei differenziellen Belastungen. 